\title{
PHILOSOPHY OF EDUCATION
}

UDC $140.8+330.366+378.1$

DOI: https://doi.org/10.30839/2072-7941.2018.155556

\section{ON IMPROVING THE QUALITY OF MODERN HIGHER EDUCATION AND SPIRITUAL AND MORAL EDUCATION OF YOUTH: GERMAN AND OTHER EUROPEAN EXPERIENCE}

\author{
(C) BLAGININA, S. V. \\ Nizhyn Nikolai Gogol State University (Nizhyn, Ukraine) \\ E-mail: blagininasvitlana@gmail.com, ORCID: 0000-0002-0000-8555 \\ (C) PYLYPENKO, S. P. \\ Kyiv Medical University (Kyiv, Ukraine) \\ E-mail: pylyp909@ukr.net, ORCID: 0000-0001-8680-834X \\ (C) OSNATCH, O. M. \\ Kyiv Medical University (Kyiv, Ukraine) \\ E-mail: asalexosnach@gmail.com, ORCID: 0000-0001-7973-6683.
}

\begin{abstract}
The relevance of the study has two sides - individual and general. In its essential aspect, it is the development of achievements of predecessors by consistently taking into account the latest data on trends and changes in the interconnected spheres of education, economics and culture. In the individual aspect, it is about improving the professional means of improving the efficiency of teaching foreign languages in order to form students with a high level of linguistic-professional competence. Public relevance is the goal of educating young people in a new patriotic direction, because today, due to various global influences, the classical principles of life in the agrarian system (in which Ukrainians have a good national heritage), created in recent centuries, or in the industrial society, are devalued due to various global influences. The purpose of the study in a broad sense was to highlight the causes and consequences of the European religious Reformation as the main factor in accelerating the movement of the whole of Western Europe to the position of the world leader that previously belonged to China. We see precise tasks in the integrated analysis on the basis of the latest discoveries of many humanities and exact sciences in the educational, economic and cultural systems of Germany and other successful European states. On this basis, we hope to fulfill the public task which is to make significant proposals in the plans and practice of higher education reform in Ukraine. The methodology of the study relies on the best classical means, on the principle of historicism and the continuity of the connection between the material and the ideal, a modern multidisciplinary approach. For the highest effectiveness of the research, we will use the latest scientific data and recommendations of the innovators who collect and use these data. The results of the study mostly follow from the mentioned new discoveries. They testify that in ancientt history, in the role of locomotives of civilizational progress in the western part of Eurasia, direct descendants of the inventors of agriculture acted, among which the especially great contribution (domestication of the horse, the invention of the wheel and the efficient metallurgy of copper) belongs to the ancestors of Ukrainians from the territories of Trypillya and the Great Trypillya. It is indicated that during
\end{abstract}

(C) Blaginina S. V., Pylypenko S. P., Osnatch O. M., 2018 
the existence of the Great Trypillya, future German farmers acquainted themselves with the technologies of the Great Trypillya, so the German language, through borrowed words, became part of the Indo-European family. It is noted that after the collapse of the Great Trypillya, the Germans and Slavs became neighbors along the meridian Elbe. In the age of steppe invasions, future Ukrainians and Germanic tribes did not get in contact, and the influence of the Roman Empire was mostly experienced by western lands. Emphasis was placed on the evolution of ideological, religious and other paradigms in the territory of Germany after the collapse of the Holy Roman Empire, which determined the development of the nation for the next hundreds of years. The religious and philosophical paradigmatic origins of those unique features of culture and education that during the nineteenth century were emphasized. brought Germany to the position of the scientific and technological leader of the world. The high role of German neo-humanism and the Berlin Research University were noted. In the final section, special attention is paid to religious issues and to the destructive impact on social and other processes in the German immigration flows of Islamists. The conclusions focus on the competition of several important paradigms in the education of modern Germany and the proposals made to incorporate German experience in legislation and the use of the Bologna process. An important caution is made regarding the choice of Germany's strategy for the development of the scientific and educational complex 'within the framework of the Lisbon project (2000). This country has become a world leader not only in alternative energy, but also in the implementation of the fourth industrial revolution. We consider an example of this leadership like the regular world conferences in Davos, which involve the majority of influential politicians and economists (in particular, from Ukraine)

Key words: evolution of humanity, history of education, higher education, Indo-European world, Germany, Reformation, Protestantism, spirituality, ethics of labor, German vector of development

Actuality. Our analysis of the world's most important political, economic, and educational decisions, recommendations and plans showed a clear predominance of entirely pessimistic visions of the future and a variety of ideas for the salvation of humanity.

There was a conviction that this task could be fulfilled only by all humanity together, and not by a single large state. The organizers and participants of the three global environmental forums (Rio de Janeiro 1992, Johannesburg 2002, Rio de Janeiro 2012) were not among the environment-friendly technologies, therefore, they proposed reducing harmful emissions and maximizing recovery and reuse. The overwhelming majority of proposals $[7 ; 10 ; 11]$; including the most recent ones [12], envisaged changes in the outlook of all representatives of new generations by means of education and a very long primary education from birth up to the labor market. Consequently, the topic of spiritual and moral education of young people becomes more and more relevant simultaneously with the aggravation of world crises.

That is why we planned and carried out this research, which coincided with the educational projects of our university. In the individual aspect, it is aimed at improving the professional means of improving the efficiency of teaching foreign languages in order to form

On improving the quality of modern higher education and spiritual and moral education of youth: german 
students with a high linguisticprofessional competence. To ensure general social relevance, we focus on educating the youth in a new patriotic sense, in particular, for the ability to win in the complex confrontation imposed on us by "fraternal Russia".

As the general objective of the study, we chose to study the causes and consequences of the European religious Reformation as the main factor in accelerating the movement of the whole of Western Europe to the position of the world leader, which at the turn of the year 1500 belonged to China.

We see precise tasks in the integrated analysis on the basis of the latest discoveries of many humanities and exact sciences in the educational, economic and cultural systems of Germany and other successful European states. On this basis, we hope to fulfill the public task - to make significant proposals in the plans and practice of higher education reform in Ukraine.

The methodology of the study relies on the best classical means, on the principle of historicism and the continuity of the connection between the material and the ideal, a modern multidisciplinary approach. For the highest effectiveness of the research, we will use the latest scientific data and recommendations of the innovators who collect and use these data.

\section{Presenting main material.}

Equally important, we considered the works of philosophers, psychologists, teachers and representatives of exact sciences. Let's mention, for example, the famous (c) Blaginina S. V., Pylypenko S. P., Osnatch O. M., 2018
Ukrainian philosopher and teacher P.Y. Saukh, whose individual books have thousands of pages. In the bookgeneralization of all the twentieth century, he expects great hopes in the development of Ukraine and the solution of environmental problems to a combination of "anthropological revolution" and "renewed Christian church." [7, p. 63-64]. (It would be interesting to see in his some of his new work a response to the remarkable event - a return home in January 2019 of the Orthodox Church of Ukraine). We have encountered the same type of reasoning in the scientific writings of many authors ([10; 11], etc.). We will continue the presentation of the results of our study of the problems of today and foreign experience of moral and spiritual education of children and youth.

It is worth mentioning that the vast majority of authors from the postSoviet territories and many foreign countries using the phrase "spiritual upbringing" mean the introduction of religious or similar subjects into the educational process. Not considering this point of view as the only correct one in the early 21 st century, we will not criticize it, and we will continue to have in mind this version of the content of this concept.

It is not a secret that even the richest and most civilized countries in Europe have significant problems with the regulation of adolescent behavior. We restrict ourselves to only two examples - periodic teenage "uprisings" in the vicinity of Paris and several other cities in France, accompanied by various acts of vandalism, as well as the destruction 
of several relatively poor neighborhoods in London by their inhabitants in mid-August 2011. With considerable delay, Ukraine at the end of 2018 also drew legislative attention to destructive teenage phenomena (first of all, bullying). The scope of the article does not allow us to give a deep analysis of the problem, so let's emphasize only that in this topic should rely not on the psychology of Freud's times, but on the opening of the sciences of the early twenty-first century. It is the ignorance of these achievements that we can explain the fact that we have more and more to traditional means of education for the education of children and young people to attract means of religion, rather than the newest exact sciences.

Two turns are aided by this turn of educational affairs: 1) "European ethno-religious renaissance" [6]; 2) disappointment in the expectation of the effective use of the values of a market-liberal society and common in the continental churches. For example, in Germany "... there is a departure from traditional religious values. Every year many thousands of people leave the Catholic and Protestant churches. Even the exclusively liberal policy and position of the Protestant church, which allows, for example, women's priesthood, divorce of clerics, homosexual marriages, can not stop the process of mass exodus from the church "[1, p.107].

In our opinion, this phenomenon can not be explained by the disappointment of German citizens with a decline in living standards or the burden of unemployment. Under the auspicious leadership of A. Merkel and the cooperation of several political parties, this country, better than other EU states, has overcome all recent global financial and other crises. Germany became the main economic savior of the European Union, shaken from the reckless social and fiscal policies of Greece, which for many years lived wealthy not by their own efforts, but at the expense of other states. In the end, since 2011, the Germans have regained world leadership of the value of exported goods, having earned them an astronomical sum of over one thousand billion euros.

The possible reason for this disappointment of many Germans in the traditional-spiritual instruments of association is to diminish the influence of those great social ideas that in the past have successfully grasped the Germans for joint action: the formation of a great nation in the nineteenth century, the restoration of peaceful life and the overcoming of painful lessons of ideological blindness of the teachings of Nazism in the second half of the twentieth century, the merging of two hostile states (FRG and GDR) into a successful national unity after the complete collapse of communism in Europe and the collapse of the Soviet Union, which held in Germany a large and most capable part of its giant army. Overcoming the problems of combining the "wessi" and "ossi" (western and eastern Germans) and significant economic successes of the first decade of the twentieth century. in some way, reduced the curiosity of most citizens to major national tasks. 
It is possible that this was because they did not exist, or they were not sufficiently emphasized by the heads of state, too concerned about almost continuous actions to save the whole of the European Union.

In the meantime, the ethical and moral sphere that was sensitive to various influences could not itself be in such a state as the modern, too needs. Let us quote the opinion of German scholars about their native country: "The demographic situation in Germany is characterized by a decline in the number of young people with a sharp increase in the number of foreign children born in German territory. According to the latest statistics, immigrants in Germany are much more likely to become clients of all kinds of psychological and social services than representatives of the local population. In addition, they are characterized by a lower educational level, the prevalence of unemployment and social stratification. This is especially true of the younger generation. " [1, p. 105].

Germany can serve for other democratic states as an example of what will inevitably lead liberalism in immigration law and the unwarranted assumption of an automatic merger of foreigners with the Germans under the influence of democracy, quality education and multicultural education. In fact, despite the almost triple increase in the "Islamic" minority in Germany, the number of those who have been working in the industry for many years remains constant. The reason for this is quite commonplace: immigrant men, after placing heterogeneous society of Germany

themselves in a permanent place of work, immediately bring home from their native country women, and, given good earnings, try to surround themselves with as many children as possible. Therefore, it is not surprising that the numbers of the economically active Islamic population are almost non-existent, and members of these non-European large families find themselves in much more difficult economic and social conditions if compared with native populations.

All first years before entering elementary school, children of immigrants hear the language of mothers, parents and other relatives, rarely playing with German peers. Bauer E. notes with sadness: "Insufficient knowledge of the German language, lack of education, bad chances in the labor market and, as a result, uncertainty in the future is typical of many immigrant families. It often makes suffer children who can not combine two cultures - native and german - and integrate into German society. Studies show that psychological problems of children and adolescents from immigrant families are most characteristic of them: aggression, predisposition to delinquent behavior, poor school performance, tense relationships with peers and teachers, lack of interest in education and further professional activity "[1, with. 105].

It was under this scenario that went the events in France and the UK, whose governments also contributed to immigration. The situation in the Belgium, the Netherlands, Spain, Italy, Portugal and Greece is approaching the crisis point. The (c) Blaginina S. V., Pylypenko S. P., Osnatch O. M., 2018 
alarming signs of increasing the capacity of "immigrant bombs" in the territories of Sweden, Norway and Finland are rather tangible. Intelligent legislative protection of national culture and coherence still saves Switzerland and Austria. As for the situation in the Russian Federation - it is sufficiently well known for the Ukrainian reader, so we will not comment on it. Let's draw from the above foreign experience only one harsh remark: every Ukrainian economist or politician, who will try to solve economic-demographic and other problems of Ukraine by means of inviting labor from Islamic, Buddhist or any other areas where culture, customs and life (first and foremost, spiritual values) are very different from those that have been formed on our forest-steppe chernozems during the last 10,000 years, will be the enemy of the Ukrainian people. It is worth pointing out that scientists have recently learned to accurately measure the age and genetic characteristics of archaeological finds. This already forces us to form a new vision of the history of Eurasia and provides a large number of facts about the genetic community and the cultural similarity of the true history of Ukrainians and Germans. In working with students, we rely on the articles by K. Korsak and his research team, who analyze the most recent discoveries of scientists. In particular, with regard to the appearance of the entire IndoEuropean culture $([4 ; 5 ; 15 ; 16]$, etc.).

And what can we borrow from the latest German experience in solving education problems? If we turn to
German-language, Russian-language or other materials, it turns out that there are no breakthroughs in overcoming the above and other problems and it is not even anticipated. They stated that in most European territories, as in Germany, youth alcoholism and drug abuse, manifestations of criminal aggression, a clear reluctance to create a legitimate family and the so-called "Civil marriage", a small number of children per one woman, mass media admitting "non-traditional sexual orientations", primitiveness of desires and frank consumerism.

In our opinion, Europe and the whole civilized world are "guilty of it" in this. Having adopted and extended the international convention on human rights, they did not consider the two following conventions - "On human obligations" and "On the ethics of journalism." In materials about the aforementioned societal disturbances of immigrant origin, journalists have repeatedly stressed that delinquent young people are absolutely convinced that all life goods at the level of educated and productive citizens of France, Germany or the United Kingdom belong to them "legally and automatically" on the basis of the said convention on human rights and the fact of their stay in the territories of the specified states.

Extremely informative and demonstrative in this sense is the recognition of the already mentioned German scientist E. Bauer: "Along with teaching in schools the foundations of the Catholic and Protestant doctrine (from 2006 - and the foundations of Orthodox doctrine), 
from the III grade of primary school it is obligatory Sexual education course. In essence, this can be characterized as the corruption of children and adolescents, which leads to the awakening of their early interest in the sexual sphere and early onset of sexual activity in them. At the same time in schools there are no lessons on the psychology of family life. It is also aggravating that the teacher in Germany has no right to influence a child. His task is to convey to him the knowledge and skills "[1, p.106].

Every phrase (even its particle!) deserves a very detailed analysis and a detailed comment. An example is the mention of teaching at a school, starting in 2006, the basics of the Orthodox doctrine. This step has witnessed an ever-increasing turning point in Germany's immigration policy aimed at attracting "white" people to themselves. They did not tempt the Americans or Canadians, but from the territories of Russia, Kazakhstan, Ukraine and parts of other ex-Soviet states they received an increased flow of new citizens (not only ethnic Germans, often Jews, Russians, etc.). If the "East European" immigrants have an impact on these religious subjects, then it is too small for young Islamists who, by the time they study in a European school, learn to study the entire Koran by chance in informal "Qur'anic institutions".

Absolutely correct and confirmed events in several European countries are the following statement by $\mathrm{E}$. Bauer: "... from the 3rd grade elementary school a course of sexual education is compulsory. In essence, this can be described as the corruption of children and adolescents. " In terms of the permissibility of the activities of the media and the rather liberal German legislation on the activities of the "sector of sexual services," the "education" becomes a powerful "anti-social", which later entails a large ploy of various personal and social problems, distortions and even perversions.

Probably the biggest one for all of the twentieth century number of mistakes in the question of sexual education was made by Sweden, which at that time had a lot more than all other states, because it did not participate in both world wars. In a condensed form, the entire evolution of sexual education and sexual education in Sweden is put into several lines:

- with the beginning of the twentieth century. within the framework of intentions to expand the "vital scientific knowledge" for young people and all interested persons conducted open lectures on the topics of anatomy and hygiene of sexual life;

- Commissions of enthusiasts in the 1920's created the first programs of several stages of sexual education of students, starting with the 1 st class. At first, most teachers and the Ministry of Education successfully relied on these intentions;

- unfortunately, the resistance of the moderates was overcome during the war: the course of sexual education by the royal decree in 1942 was introduced as an elective, and after 1955 became an obligatory subject;

- after several years of tales for children and adolescents about 
effective ways of getting sexual pleasure and almost complete inattention to the issues of marriage and family, the Swedes managed to accumulate the majority of moral and educational anti-rectors: 1) the highest number of mental illnesses in the world (1970); 2) a record level of suicide (1971); 3) an unprecedented wave of sexually transmitted diseases $(1965-1970)$; 4) the continuous growth of cases of pregnancy of teenage girls; 5) the mass of abortions, an increase in the number of births of children before marriage (in 1974 $28 \%$ of the total); 6) the growth of acts of vandalism and aggression among young people; the spread of forms of sexuality that lead to the degradation and self-destruction of the person (www.rfsu.su);

- Since the mid-1970s, the Swedes have been trying to correct these mistakes and return to the state of study and public morale that existed in the 1930-1940s. So far - with little success.

In the article by K.Korsak, "The Hidden Dangers of Sexual Education," noted [3] that attempts in Polish socialist society to develop gender studies in the "Swedish model" had much weaker destructive consequences for a trivial cause due to lack of funds, everything was confined to small optional courses for part senior pupils (about 20-25\% of the total) and, fortunately, did not cover the general pupils of junior classes. His article was a response to the first general informative works of O. Secheyko in "Native school" on the topic [8;9], as well as the fact that Ukraine "escaped" from the potential dangers of sexual education due to the lack of large-scale state programs for its implementation. The criticism of Russian scientific publications on sexual education (I.Kon, O.Zubets, etc.) deserves special attention, which relied only on outdated psychological and pedagogical views and completely ignored the important ones for explaining the teenage crisis, emotional suicides, delictual behavior, and others phenomena of a whole group of young sciences about man the newest sections of ethology (evolutionary psychology), neuromolecular physiology of emotional states, theories of brain activity, human ecology, and others. In support of the above-mentioned actions of the Ministry of Internal Affairs of Ukraine in the field of countering bullying and other phenomena, we emphasize once again that understanding these threats and successful struggle with them requires the active use of these (example of proposals - in [5]) rather than classical psychological and pedagogical knowledge.

If $\mathrm{E}$. Bauer in his generalization calls contemporary German society "a society of mass disbelief" [1, p.107], then perhaps there are better examples of moral and spiritual education of youth in societies of "mass faith"? What causes such faith in the Middle East and in many other parts of the world to be detailed on will. Unfortunately, the restoration of religious and spiritual life in the Ukrainian and Russian territories is in a deformed way and does not even give the slightest expectation that a so cohesive and perfectly renewed Christian church will suddenly emerge On improving the quality of modern higher education and spiritual and moral education of youth: german 
that will cause general enthusiasm and lead the Ukrainian people to a dream 1000 -later "kingdom of peace, happiness and harmony". Foreign scholars and politicians point out that a very strong alliance between secular and religious $\mathrm{n}$ supreme authorities arose, based on the identities of their interests. The consequence was accelerated "religization" of the educational system, which occurs contrary to the opinions of scientists and even prominent religious thinkers. The representatives of the exact sciences and the humanities are undoubtedly afraid that the funds of the Russian budget will go not to the technological progress of the state, but to religious propaganda outside its borders (in particular, to complete the construction of grand temples in Kyiv and other Ukrainian cities). After several years of fruitful and active work of a group of theologiansscientists representing several widespread religions in Russia, conclusions and other materials were published, in which it was necessary: it was impossible to bring religious education into schools in Russia with only positive results (unity of nations and churches, strengthening of Russia , the disappearance of religious terrorism, etc.) [2]. However the authorities have ignored these materials and have since 2009 made the religious subject "Orthodox spirituality" mandatory for all general educational institutions.

In order to deepen our analysis in the aspect of searching for parallels between Germany and Ukraine, we will perform a brief comparison of classical and recent scientific results. In the framework of comparative linguistics, German and other scientists proved that the array of common Indo-European words originates from the Ukrainian-Russian forest-steppe. They introduced the concept of proto-Indo-European language and postulated its spread, as shown in Fig. 1.

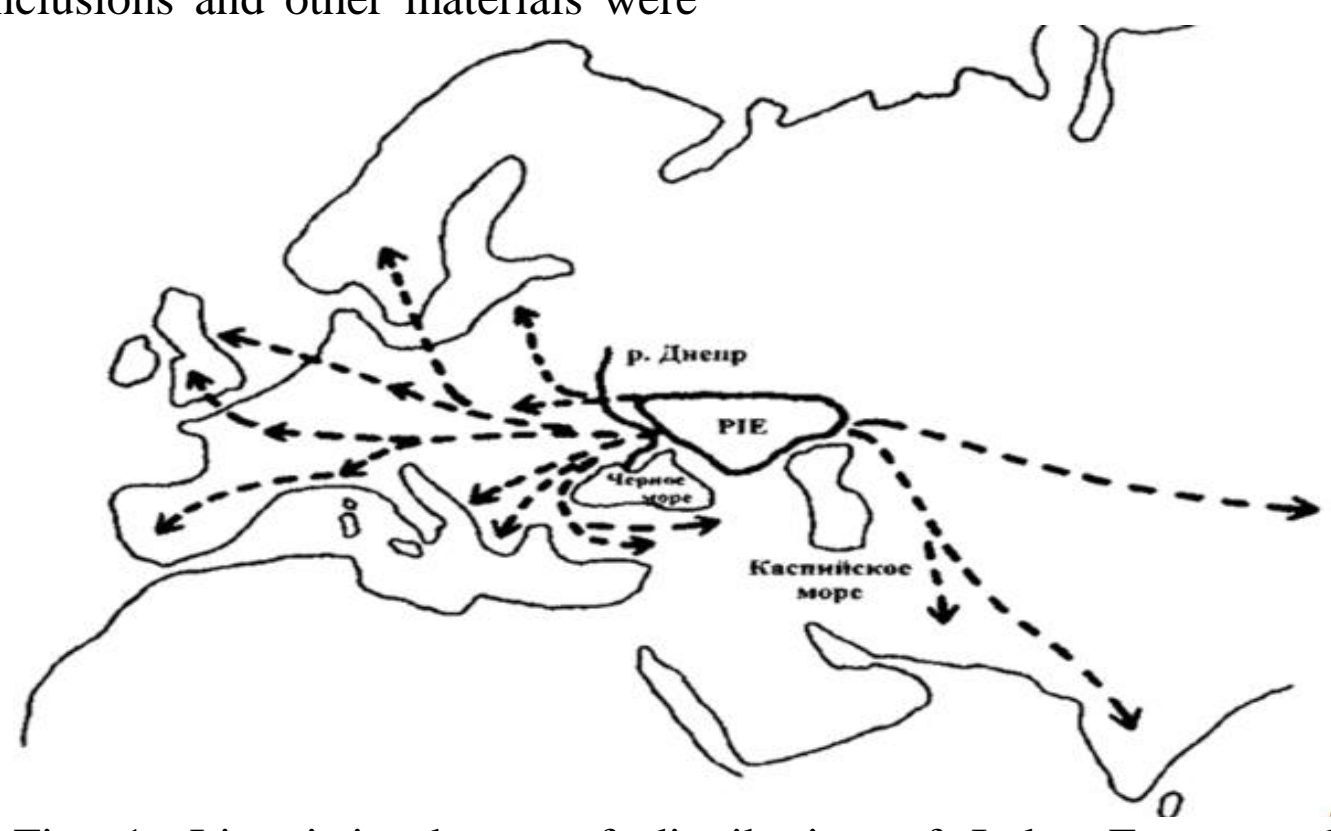

Fig. 1. Linguistic theory of distribution of Indo- European languages [14, Fig.8.] 
The use of the latest isotopephysical and genetic-biological data suggests that the ancestors of both nations participated in the invention of agricultural production in the Middle East from the limit of 8-9 thousand years $\mathrm{BC}$ and in its spread towards the Atlantic ocean[13]. Ukrainians on the Eastern coast of Bulgaria came" home " 9000 years ago, and the Germansfarmers did it later for 1-2 thousand years, moving along the Danube valley. The set of genes of women from both nations in the future has changed relatively little, but the men were replaced by Aryans with DNAhaplogroup R1a (Fig. 1 believed that the arrows on it meant the movement of the Aryans)

The ancestors of Ukrainians made a great series of economic achievements in the areas of Trypillya-Kukuteni and Great Trypillya, which led to the spread of new words-tags between the Atlantic and China and the birth of the Indo-
European linguistic and cultural community (a detailed description of the phenomena based on the latest discoveries is present in the article [15] and other publications of Korsak). As a result of a series of natural and other disasters, a significant part of the population of the Western part of the Great Trypillya with haplogroups R1a moved towards the Atlantic ocean and by force colonized all the territory up to the Meridian of Berlin, forming the basis of the Western part of the Slavic world. As they have stopped, approximately 3000 years ago, the male population of modern German territories, as we assume, has suffered the first division into "Wessi "(R1b) and" Ossi" (R1b). To confirm this assumption, we can mention two facts: 1) the huge quantity of Slavic names of villages and hamlets to the eastfrom Berlin; 2) the modern distribution of the male haplogroup R1a and R1b in Fig.2.

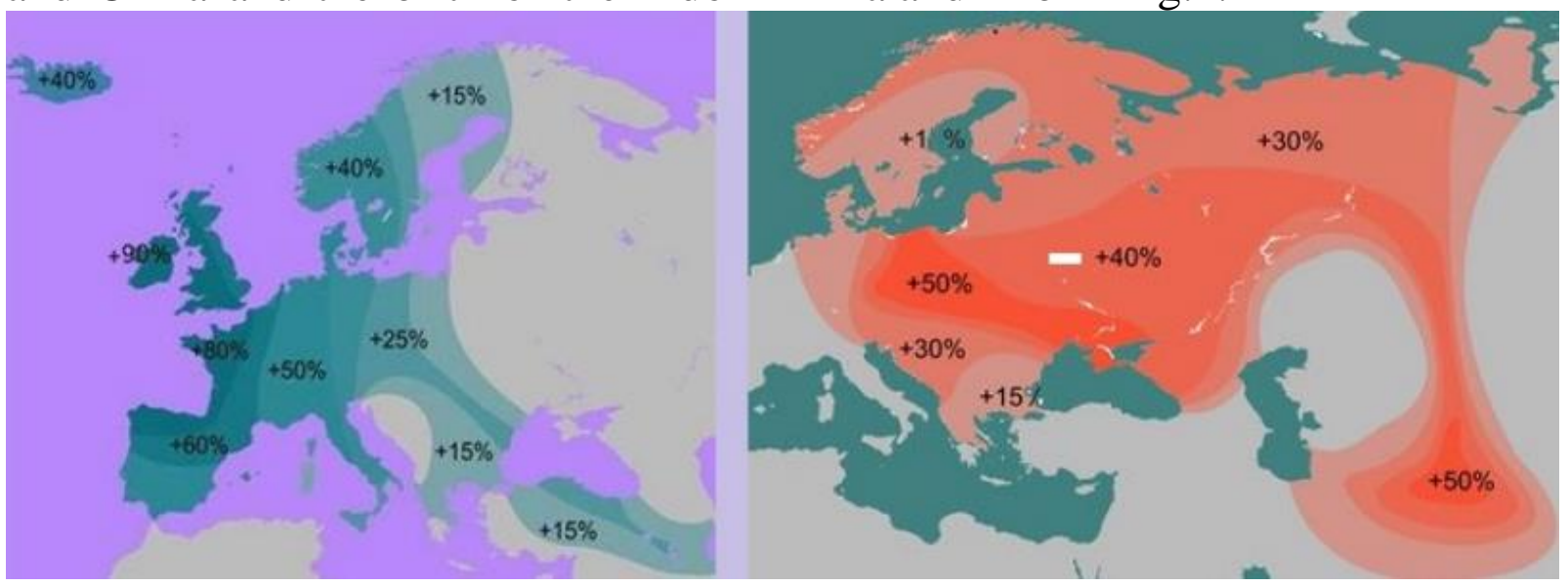

Fig. 2. Distribution of Y-chromosomal haplogroups R1b and R1a nowadays (http://austrasia.ru/news/9/57/dorogi-severnogo-naroda.html and other sources were used).

We consider the multidisciplinary manifestations of a very long-standing study of the consequences and competition of the carriers of both 
haplogroups and the influence on the cultural traits and behavior of the entire German people of the interference of the traits of these groups, cases of a significant advantage of one over the other.

There is no doubt that, as ethological discoveries and theories show, human actions are based on a combination of genetic inheritance and social patterns. We will not be surprised if the facts confirm the highest community of Germans-Ossi (haplogroup R1a) with Ukrainians.

As the main conclusion of our study, we consider the prospects of using in Ukraine a positive ideological and educational experience of Germany and other EU states. Our own experience, as well as the practice of EU leaders, proves that it would be advisable to offer moral and spiritual issues to young people not within religions or similar apprenticeships, but on a much stronger basis of modern science. And the matter is not only that religious confusion dominates and increases in the world, but that the roots of the main monotheistic religions, as evidenced by the new discoveries, have 6-9 thousand years, and therefore appear to be inappropriate in their primitive-hierarchical models to the ambushes and the needs of democratic and legal states with the division of branches of power, the rule of law, the developed system of social protection, the state means of giving letters and profession to every young person, etc.

In addition, the constant and accelerated increase in the number of scientists on Earth and the best use of them, and indeed, triggered another technological revolution (K. Schwab and other conference organizers in Davos). However, they mistakenly see its referral. The creation of the "Internet of Things", blockchains and other similar eclipses less noticeable changes in the principles of production, since among the nanotechnologies from the limit of the XXI century. ecologically safe and wise technologies appear (their inventor K.Korsak offers for them the name "nootechnology" [4; 16]). This term, together with the nooscience concept, has just begun to "conquer the world", but the idea of "sustainable development" will be realized only through "development" and the construction of the noosphere according to V.I. Vernadsky The monitoring of the events in the sciences and the high school of the EU gives us the first evidence that Germany has begun to take the first steps in the development of the noodevelopment, refusing to "neoindustrialism".

\section{REFERENCES}

1. Bauer, E. A. (2010). Spiritual and moral education of children and adolescents: Germany and Russia. Pedagogy, 8,105-108.

2. Bychkov, S. (2009). Vera assembled in school. "MK" in Ukraine, 37 (596), 17.

3. Korsak, K. (2003). Hidden Dangers of Sex Education. Education and Management, 1, $162-169$.

4. Korsak, K. V., Korsak, Yu. K. (2017). Noohistory and noosciences about the possibility of the second ukrainian world spiritualization. Humanities Bulletin of Zaporizhzhe State 
Engineering Academy, 69, 112-118. doi: https://doi.org/10.30839/2072-

7941.2017.102113

5. Korsak, K. V. (2014). Osobennosti mozga podrostkov i personazhey Bol'shoy Istorii.

RELGA, 10. Available at: http://www.relga.ru/Environ/WebObjects/tguwww.woa/wa/Main?textid=3978\&level1=main\&level2=articles

6. Lozko, G. S. (2006). Aeneas is awakened. European ethno-religious renaissance. Kharkiv: See, 464.

7. Sauk, P. Yu. (2009). XX century. Results. Kyiv: "Les Lesya", 284.

8. Sečiiko, O. (1999). To the problem of sexual education. Native school, 1, 25-26.

9. Sečiiko, O. (1999). The attitude of adolescents to sexual problems. Native school, 3 , $57-58$.

10. Solnechny, E. (2012). Coaching of a sick society. The Unknown World, 2, 17-23.

11. Ursul, A. D. (2008). "Salvation" Education Mission for Sustainable Development. Bulletin of the Higher School (Alma mater), 11, 22-30.

12. von Weizsaecker, E., Wijkman, A. (2018) Come On! Capitalism, Short-termism, Population and the Destruction of the Planet. Springer, 220. doi:

https://doi.org/10.1007/978-1-4939-7419-1

13. Diamond, J. (2005). Guns, Germs, and Steel. The Fates of Human Societies. W. W. Norton \& Company New York London, 457.

14. Diamond, J. (2013). The third chimpanzee. Moscow, ACT, 242.

15. Korsak, K. V. (2017). Introduction to the noohistory and the new Ukrainian national idea-XXI. Humanities Bulletin of Zaporizhzhe State Engineering Academy, 68, 68-77. doi: https://doi.org/10.30839/2072-7941.2017.94386

16. Korsak, K. V., Korsak, Y. K. (2018). The only way to save humanity from total collapse - nootechnologies and noosciences. Humanities Bulletin of Zaporizhzhe State Engineering Academy, 74, 28-38. doi: https://doi.org/10.30839/2072-7941.2018.149632

БЛАГІНІНА, С. В. - кандидат педагогічних наук, доцент, заступник декана факультету іноземних мов, Ніжинський державний університет імені Миколи Гоголя (Ніжин, Україна)

E-mail: blagininasvitlana@gmail.com, ORCID: 0000-0002-0000-8555

ПИЛИПЕНКО, С. П. - кандидат філософських наук, старший викладач кафедри іноземних мов та соціально-гуманітарних дисциплін, ПВНЗ “Київський медичний університет" (м. Київ, Україна)

E-mail: pylyp909@ukr.net, ORCID: 0000-0001-8680-834X

ОСНАЧ, О. М. - кандидат політичних наук, старший викладач кафедри іноземних мов та соціально-гуманітарних дисциплін, ПВНЗ “Київський медичний університет” (м. Київ, Україна)

E-mail: asalexosnach@gmail.com, ORCID: 0000-0001-7973-6683

\section{ПРО ПІДВИЩЕННЯ ЯКОСТІ СУЧАСНОЇ ВИЩОЇ ОСВІТИ І ДУХОВНО- МОРАЛЬНОГО ВИХОВАННЯ МОЛОДІ: НІМЕЦЬКИЙ ТА ІНШИЙ СВРОПЕЙСЬКИЙ ДОСВІД}

Анотація. Актуальність нашого дослідження має дві сторони - індивідуальну i загальносуспільну. В сутнісному аспекті воно полягає в розвитку досягнень науковцівпопередників через послідовне врахування найновіших даних про тренди і зміни взаємопоєднаних сфер освіти, економіки та культури. В індивідуальному аспекті йдеться про вдосконалення фахових засобів підвищення ефективності викладання іноземних мов задля формування у студентів високої мовно-фахової компетентності.

On improving the quality of modern higher education and spiritual and moral education of youth: german 
Загальносуспільну актуальність складає мета виховання молоді у новому патріотичному скеруванні, адже сьогодення через різноманітні глобальні впливи знецінює створені в останні століття класичні засади життедіяльності в аграрному (тут українці мають хороший національний спадок) чи індустріальному суспільстві. Метою дослідження в широкому аспекті ми обрали вивчення причин і наслідків європейської релігійної Реформації як головного чинника прискорення руху всієї Західної Європи до становища світового лідера, що раніше належало Китаю. Конкретні завдання ми вбачаємо в інтегральному аналізі на основі найновіших відкриттів багатьох гуманітарних і точних наук подій в освітніх, економічних і культурних системах Німеччини та інших успішних європейських держав. На цій основі ми сподіваємося виконати загальносуспільне завдання - внести вагомі пропозиції в плани і практику реформ вищої освіти України. Методологія дослідження спирається на кращі класичні засоби, на принцип історизму і нерозривність зв'язку матеріального та ідеального, сучасний мультидисциплінарний підхід. Для вищої результативності дослідження скористаємося найновішими науковими даними $\mathrm{i}$ рекомендаціями науковців-інноваторів, які i накопичують ці дані, і використовують їх. Результати дослідження, більшою частиною випливають з вказаних новітніх відкриттів. Вони свідчать, що в долітописні часи у ролі локомотивів цивілізаційного прогресу у західній частині Свразії виступали прямі нащадки винахідників землеробства, серед яких особливо великий внесок (одомашнення коня, винахід колеса та ефективної металургії міді) належить пращурам українців з теренів Трипілля і Великого Трипілля. Вказано, що вже під час існування Великого Трипілля майбутні німці-землероби знайомилися з технологіями Великого Трипілля, тому німецька мова через запозичені слова увійшла у склад індоєвропейської сім’ї. Відзначено, що після розпаду Великого Трипілля німці і слов'яни стали сусідами по меридіану Ельби. У століття степових навал майбутні українці і німецькі племена контактували мало, а впливу Римської імперії зазнали переважно західні землі. Зроблено наголос на еволюції світоглядних, релігійних та інших парадигм на теренах Німеччини після розпаду Священної Римської імперії, які визначили розвиток нації на наступні сотні років. Підкреслено релігійні та філософські парадигмальні витоки тих унікальних рис культури та освіти, які впродовж XIX ст. вивели Німеччину на позицію наукового й технологічного лідера світу. Відзначена висока роль німецького неогуманізму i Берлінського дослідницького університету. У заключній частині особлива увага звернута на релігійні питання і на деструктивний вплив на соціальні та інші процеси в Німеччині імміграційних потоків ісламістів. У висновках акцентовано конкуренцію кількох важливих парадигм в освіті сучасної Німеччини і зроблені пропозиції врахування в Україні німецького досвіду у законодавстві та у використанні Болонського процесу. Зроблено важливе застереження щодо вибору Німеччиною стратегії розвитку науково-освітнього комплексу в рамках Лісабонського проекту (2000 р.). Ця країна стала світовим лідером не тільки в альтернативній енергетиці, а й у втіленні у життя четвертої промислової революції. Прикладом цього лідерства ми вважаємо регулярні світові конференції у Давосі, в яких беруть участь більшість впливових політиків та економістів (зокрема, і з України)

Ключові слова: еволюція людства, історія освіти, вища освіта, індоєвропейський світ, Німеччина, Реформація, протестантизм, духовність, етика праці, німецький вектор розвитку

БЛАГИНИНА, С. В. - кандидат педагогических наук, доцент, заместитель декана факультета иностранных языков, (Нежин, Украина)

(C) Blaginina S. V., Pylypenko S. P., Osnatch O. M., 2018 
E-mail : blagininasvitlana@ gmail.com, ORCID: 0000-0002-0000-8555

ПИЛИПЕНКО, С. П. - кандидат философских наук, старший преподаватель кафедры иностранных языков и социально-гуманитарных дисциплин ПВНЗ "Киевский медицинский университет" (г. Киев, Украина.)

E-mail: pylyp909@ukr.net, ORCID: 0000-0001-8680-834X

ОСНАЧ, О. М. - кандидат политических наук, старший преподаватель кафедры иностранных языков и социально-гуманитарных дисциплин, ПВНЗ "Киевский медицинский университет", (г. Киев, Украина)

E-mail: asalexosnach@gmail.com, ORCID: 0000-0001-7973-6683

\section{О ПОВЫШЕНИИ КАЧЕСТВА СОВРЕМЕННОГО ВЫСШЕГО ОБРАЗОВАНИЯ И ДУХОВНО-НРАВСТВЕННОГО ВОСПИТАНИЯ МОЛОДЕЖИ: НЕМЕЦКИЙ И ДРУГОЙ ЕВРОПЕЙСКИЙ ОПЫТ}

Аннотация. Актуальность нашего исследования имеет две стороны индивидуальную и общественную. В сущностном аспекте она заключается в развитии достижений ученых-предшественников через последовательный учет новейших данных о трендах и изменениях взаимосвязанных сфер образования, экономики и культуры. В индивидуальном аспекте речь идет о совершенствовании профессиональных средств повышения эффективности преподавания иностранных языков для формирования у студентов высокой культурно-профессиональной компетентности. Общественную актуальность составляет воспитание молодежи в новом патриотическом направлении, ведь настоящее через различные глобальные влияния обесценивает созданные в последние века классические основы жизнедеятельности в аграрном (здесь украинцы имеют хороший национальный наследству) или индустриальном обществе. Целью исследования в широком аспекте мы выбрали изучение причин и последствий европейской религиозной Реформации как главного фактора ускорения движения всей Западной Европы в положение мирового лидера, ранее принадлежавшее Китаю. Конкретные задачи мы видим в интегральном анализе на основе новейших открытий многих гуманитарных и точных наук событий в образовательных, экономических и культурных системах Германии и других успешных европейских государств. На этой основе мы надеемся выполнить общегражданскую задачу - внести весомые предложения в планы и практику реформ высшего образования Украины. Методология исследования опирается на лучшие классические средства, на принцип историзма и неразрывность связи материального и идеального, современный мультидисциплинарний подход. Для высшей результативности исследования воспользуемся новейшими научными данными и рекомендациями ученых-инноваторов, которые и накапливают эти данные и используют их. Результаты исследования, большей частью вытекают из указанных новейших открытий. Они свидетельствуют, что в долетописные времена в роли локомотивов цивилизационного прогресса в западной части Евразии выступали прямые потомки изобретателей земледелия, среди которых особенно большой вклад (одомашнивание лошади, изобретение колеса и эффективной металлургии меди) принадлежит предкам украинцев с территории Триполья и Большого Триполья. Указано, что уже во время существования Большого Триполья будущие немцы-земледельцы знакомились с технологиями Большого Триполья, поэтому немецкий язык через заимствованные слова вошел в состав индоевропейской семьи. Отмечено, что после распада Большого Триполья немцы и славяне стали соседями по меридиану Эльбы. В век степных нашествий будущие украинцы и германские племена контактировали мало, а влияние Римской империи испытали преимущественно западные земли. Сделан упор на эволюции мировоззренческих, религиозных и других парадигм на территории Германии после распада Священной On improving the quality of modern higher education and spiritual and moral education of youth: german 
Римской империи, которые определили развитие нации на следующие сотни лет. Подчеркнуто религиозные и философские парадигмальные истоки тех уникальных черт культуры и образования, которые в течение XIX в. вывели Германию на позицию научного и технологического лидера мира. Отмечена высокая роль немецкого неогуманизма и Берлинского исследовательского университета. В заключительной части особое внимание обращено на религиозные вопросы и на деструктивное влияние на социальные и другие процессы в Германии иммиграционных потоков исламистов. В выводах акцентировано внимание на конкуренцию нескольких важных парадигм в образовании современной Германии и сделаны предложения учета в Украине немецкого опыта в законодательстве и в использовании Болонского процесса. Сделано важное предостережение по выбору Германией стратегии развития научно-образовательного комплекса в рамках Лиссабонского проекта (2000г.). Эта страна стала мировым лидером не только в альтернативной энергетике, но и в воплощении в жизнь четвертой промышленной революции. Примером этого лидерства мы считаем регулярные мировые конференции в Давосе, в которых принимают участие большинство влиятельных политиков и экономистов (в частности, и из Украины)

Ключевые слова: эволюция человечества, история образования, высшее образование, индоевропейский мир, Германия, Реформация, протестантизм, духовность, этика труда, немецкий вектор развития.

Стаття рекомендована до публікації д.філософ.н., проф. Р. І. Олексенко (Мелітополь, Україна)

Надійшла до редколегї: 01.11.2018 p. Прийнята до друку: 06.11.2018 p. 